\title{
FAKTOR - FAKTOR KOMUNIKASI YANG MEMPENGARUHI TINGKAT KEPERCAYAAN TERHADAP TENAGA TEKNIS KEFARMASIAN
}

\section{(COMMUNICATION FACTORS THAT INFLUENCE THE TRUST LEVEL TOWARD PHARMACY TECNICIAN)}

\author{
NI PUTU UDAYANA ANTARI*; HERLEEYANA MERIYANI*, \\ NI MADE DHARMA SHANTINI SUENA* \\ *Fakultas Farmasi Universitas Mahasaraswati Denpasar \\ Jalan Kamboja No.11A, Denpasar, Bali
}

\begin{abstract}
Abstrak: Apotek adalah sarana pelayanan kefarmasian tempat dilakukan praktek kefarmasian oleh Apoteker yang dibantu oleh Tenaga Tekhnis Kefarmasian (TTK). Menurut hasil survei terhadap 50 konsumen Apotek, didapatkan hasil bahwa hanya 8 konsumen Apotek yang memilih tenaga kefarmasian untuk membantu memilihkan obat dalam swamedikasi. Berdasarkan permasalahan tersebut peneliti tertarik melakukan penelitian untuk mengetahui faktor - faktor yang mempengaruhi tingkat kepercayaan masyarakat terhadap TTK sebagai salah satu tenaga kefarmasian. Penelitian dibatasi pada faktor-faktor dari segi komunikasi khususnya di Apotek. Ditemukannya informasi-informasi yang diperlukan untuk pengembangan kompetensi TTK, khususnya dalam bidang komunikasi dengan pasien akan sangat membantu upaya peningkatan kualitas pelayanan kefarmasian. Penelitian ini menggunakan rancangan survei cross-sectional, dengan menggunakan sistem purposive sampling. Data dikumpulkan dengan menyebarkan kuesioner terstruktur kepada 100 konsumen apotek. Kuesioner terdiri dari pertanyaan terkait faktor-faktor komunikasi eksternal (daya tarik fisik apotek, daya tarik fisik TTK, familiarity, empati, dan kedekatan) dan tingkat kepercayaan masyarakat terhadap TTK di Apotek. Data dianalisis secara bivariat menggunakan uji korelasi Spearman dan analisis multivariat menggunakan regeresi linear. Ada lima faktor yang diuji, yaitu; daya tarik fisik TTK, daya tarik fisik Apotek, empati, familiarity, dan kedekatan. Menurut hasil analisis bivariat semua faktor berpengaruh pada tingkat kepercayaan pasien kecuali faktor familiarity. Sedangkan jika diuji secara simultan menggunakan regresi linear, hanya faktor empati dan daya tarik fisik apotek yang dianggap cukup berpengaruh terhadap persamaan yang dihasilkan.
\end{abstract}

Kata kunci: Apotek, Kepercayaan, Komunikasi, Pelayanan Kefarmasian

Abstract: Pharmacy is a health service facility conducted by pharmacists who are assisted by Pharmacy Technician (TTK). According to the results of a survey of 50 pharmacy consumers, it was found that only eight pharmacy consumers chose pharmacy staff to help choose drugs in self-medication. Based on the problems researchers are interested in conducting research to find out the factors that influence the level of public trust in TTK as one of the pharmacy staff. Research is limited to factors in terms of communication, especially at the Pharmacy. The discovery of information needed for the development of TTK competencies, especially in the field of communication with patients will greatly help efforts to improve the quality of pharmaceutical services. This study used a cross-sectional survey design, using a purposive sampling system. Data was collected by distributing structured questionnaires to 100 pharmacy consumers. The questionnaire consisted of questions related to external communication factors (the pharmacy's physical attractiveness, TTK physical attractiveness, familiarity, empathy, and closeness) and the level of public trust in TTK at the Pharmacy. Data were analyzed using bivariate analysis (Spearman correlation test) and multivariate analysis using linear regression. There are five factors tested, namely; physical attraction of TTK, pharmacy's physical attractiveness, empathy, familiarity, and closeness. According to the results of bivariate analysis all factors influence the level of patient confidence except the familiarity factor. Whereas if tested simultaneously using linear regression, only the empathy factor and physical attractiveness of the pharmacy are considered to have sufficient influence on the equation produced.

Keywords: communication, pharmacy, pharmaceutical care, trust.

\footnotetext{
•email korespondensi: putuudayana87@gmail.com
} 


\section{PENDAHULUAN}

Tuntutan pasien akan mutu pelayanan kefarmasian mengharuskan adanya perubahan paradigma pelayanan dari paradigma lama yang berorientasi pada produk obat, menjadi paradigma yang baru yang berorientasi kepada pasien (Suharman, 2011). Kegiatan pelayanan kefarmasian yang semula hanya berfokus pada pengelolaan obat sebagai komoditi meningkat menjadi pelayanan yang komprehensif yang bertujuan untuk meningkatkan kualitas hidup pasien. Menurut Gordon (2015) meningkatkan komunikasi sangat penting jika kita ingin berubah menjadi sistem perawatan kesehatan yang berorientasi pada nilai lebih. Komunikasi yang berkualitas antara tenaga kesehatan dan pasien telah terbukti memiliki pengaruh positif pada hasil kesehatan pasien.

Apoteker dan Tenaga Teknis Kefarmasian (TTK) merupakan tenaga kesehatan yang mempunyai peran penting dalam menghasilkan pelayanan kefarmasian yang berkualitas. Harapan pasien atas pelayanan kefarmasian dibentuk oleh banyak faktor, diantaranya informasi yang diterima pasien dari lingkungan sekitarnya, pengalaman atas penggunaan jasa yang sama sebelumnya, dan kesan pasien atas organisasi yang menyediakan layanan jasa tersebut (Antari, 2011). Belum terpenuhinya harapan konsumen bisa terjadi akibat kurangnya tenaga kefarmasian yang benar-benar terlatih untuk memberi pelayanan kefarmasian, khususnya dalam menyampaikan informasi obat. Coiera (2006) juga menyampaikan bahwa perawatan primer di banyak negara berada di bawah tekanan, dengan terbatasnya sumber daya, sementara permintaan konsumen terus meningkat untuk akses keperawatan. Komunikasi yang buruk dapat menimbulkan berbagai hasil negatif: perawatan yang tidak berkelanjutan, keselamatan pasien kurang diperhatikan, sumber daya yang berharga tidak digunakan secara efisien, ketidakpuasan pasien, beban kerja dokter yang berlebihan, dan konsekuensi ekonomi. Sementara hasil negatif tersebut sering tersembunyi (Vermeir, 2005).

Komunikator yang dipandang menarik (karena kesamaan, kedekatan, daya tarik fisik) lebih efektif dalam mempengaruhi perubahan pendapat. Kepercayaan memberikan perspektif pada manusia dalam mempersepsi kenyataan, memberikan dasar bagi pengambilan keputusan dan menentukan sikap terhadap objek sikap. Rasa "percaya" meningkatkan komunikasi interpersonal karena membuka saluran komunikasi, memperjelas pengiriman dan penerimaan informasi, serta memperluas peran komunikan untuk mencapai maksudnya. Sejauh mana kita percaya pada orang lain dipengaruhi oleh faktor-faktor personal dan situasional (Rakhmat, 2011).

Peneliti tertarik melakukan penelitian untuk terkait faktor-faktor yang mempengaruhi tingkat kepercayaan masyarakat terhadap TTK dilihat dari segi komunikasi khususnya di Apotek. Faktor-faktor yang diamati dalam penelitian ini diantaranya: daya tarik fisik TTK, daya tarik fisik Apotek, empati, familiarity, dan kedekatan. Penelitian ini diharapkan dapat memperkaya informasi yang diperlukan untuk pengembangan kompetensi tenaga tekhnis kefarmasian, khususnya dalam bidang komunikasi dengan pasien.

\section{METODE PENELITIAN}

Rancangan Penelitian. Penelitian ini menggunakan rancangan survey cross-sectional, dengan menggunakan sistem purposive sampling.

Populasi dan Sampel. Populasi dalam penelitian ini adalah seluruh pasien apotek di Kota Denpasar. Jumlah sampel ditentukan berdasarkan rumus (Lemeshow dkk.,1997) ;

$n=\frac{Z_{1}^{2}-\overline{\overline{2}} \cdot p(1-p)}{d^{2}}$

Keterangan:

n : jumlah sampel minimum

$Z_{1}^{2}-\frac{\overline{2}}{2}$ : derajat kepercayaan $95 \%(1,96) 2$

p : proporsi populasi $50 \%(0,5)$

d : tingkat presisi/penyimpangan terhadap populasi $10 \%(0,10)$

Menurut rumus, diperoleh jumlah sampel minimal 96 responden dan dibulatkan menjadi 100 responden. Terdapat empat apotek sampel yang diambil dari masing-masing kecamatan di kota Denpasar. Diantarnya Kecamatan Denpasar Utara, Denpasar Timur, Denpasar Selatan, Denpasar Barat. Dengan demikian, diambil 25 responden dari masing - masing apotek sampel. Responden yang diambil harus memenuhi kriteria inklusi dan ekslusi berikut.

Kriteria inklusi:

a. Konsumen apotek yang berumur 17-60 tahun yang berbelanja ke Apotek dan ditangani langsung oleh TTK. 
b. Konsumen apotek yang berpendidikan minimal SD.

c. Konsumen apotek yang membeli obat bebas atau obat bebas terbatas tanpa resep dokter.

d. Konsumen apotek yang telah menerima layanan dari TTK di Apotek tersebut.

Kriteria eksklusi:

a. Konsumen apotek yang tidak bersedia mengisi kuesioner.

b. Konsumen apotek yang tidak dapat membaca serta menulis.

Instrumen Penelitian. Alat penelitian adalah kuesioner yang terdiri dari pertanyaan - pertanyaan terkait penilaian konsumen terhadap faktor-faktor komunikasi eksternal dan tingkat kepercayaan konsumen terhadap TTK. Faktor-faktor komunikasi eksternal yang dinilai adalah daya tarik fisik apotek, daya tarik fisik TTK, familiarity, kedekatan, dan empati. Daya tarik fisik yang dimaksud yaitu daya tarik fisik TTK yang bertugas di apotek dan daya tarik fisik apotek. Familiarity yang dimaksud yaitu TTK yang bertugas di Apotek sudah familiar atau dikenal; dipahami; umum; sering; akrab. Kedekatan yang dimaksud adalah terdapatnya kesamaan antara TTK dengan responden, misalnya kesamaan tempat tinggal, kesamaan tempat lahir, kesamaan gaya bicara dan kesamaan kesenangan. Empati yang dimaksud adalah keadaan mental yang membuat seseorang merasa atau mengidentifikasi dirinya dalam keadaan perasaan atau pikiran yang sama dengan orang atau kelompok lain. Empati yang dinilai dalam penelitian adalah rasa empati TTK terhadap pasien. Kepercayaan yang dimaksud yaitu kepercayaan responden terhadap TTK.

Kuesioner yang digunakan merupakan kuesioner tertutup yang dinilai menggunakan skala Likert. Kuisioner yang akan digunakan dikonsultasikan dengan ahli Bahasa Indonesia serta diuji validitas dan reabilitasnya terlebih dahulu. Uji validitas yang digunakan adalah tekhnik korelasi Product Moment Pearson. Validitas kuesioner ditentukan dengan membandingkan antara " $\mathrm{r}$ hitung" dan "r tabel". Kuesioner yang memenuhi syarat uji validitas adalah kuesioner yang memiliki $r$ hitung $>r$ tabel $(r$ hitung $>0,361$ ). Pengukuran reliabilitas dilakukan dengan metode one shot (sekali ukur). Kriteria pengujian adalah jika nilai Cronbach Alpha hitung >60, maka kuesioner yang diuji dinyatakan telah reliabel dan memenuhi syarat untuk digunakan sebagai alat ukur. Pertanyaan - pertanyaan yang tidak memenuhi syarat uji validitas dan reliabilitas digugurkan. Sisa pertanyaan disusun kembali untuk dijadikan alat penelitian.

Pengolahan dan Analisis data. Data dari kuesioner diterjemahkan menjadi data kuantitatif dengan ketentuan sesuai tabel 1 .

Tabel 1 Penilaian pernyataan kuesioner

\begin{tabular}{lllll}
\hline \multirow{2}{*}{ No. } & \multicolumn{2}{c}{ Favourable } & \multicolumn{2}{c}{ Unfavourable } \\
\cline { 2 - 5 } & Pernyataan & Nilai & Pernyataan & Nilai \\
\hline 1. & $\begin{array}{l}\text { Sangat } \\
\text { Setuju }\end{array}$ & 5 & $\begin{array}{l}\text { Sangat } \\
\text { Setuju }\end{array}$ & 1 \\
\hline 2. & Setuju & 4 & Setuju & 2 \\
\hline 3. & $\begin{array}{l}\text { Kurang } \\
\text { setuju }\end{array}$ & 3 & $\begin{array}{l}\text { Kurang } \\
\text { setuju }\end{array}$ & 3 \\
\hline 4. & Tidak Setuju & 2 & $\begin{array}{l}\text { Tidak } \\
\text { Setuju }\end{array}$ & 4 \\
\hline 5. & $\begin{array}{l}\text { Sangat } \\
\text { Tidak Setuju }\end{array}$ & 1 & $\begin{array}{l}\text { Sangat } \\
\text { Tidak } \\
\text { Setuju }\end{array}$ & 5 \\
\hline
\end{tabular}

Data yang dikumpulkan dianalisis secara bivariat untuk mencari korelasi antara masing-masing variabel bebas dan variabel terikat. Analisis multivariat digunakan untuk menguji hubungan antara semua variabel bebas dan variabel terikat.

\section{HASIL DAN PEMBAHASAN}

\section{Hasil uji validitas dan reliabilitas kuesioner}

Kuesioner disusun dan dikonsultasikan ke ahli Bahasa Indonesia untuk memastikan kuesioner yang akan digunakan telah memenuhi kaidah Bahasa Indonesia yang baik dan benar. Kuesioner yang disusun terdiri dari pertanyaan-pertanyaan terkait kepercayaan, empati, kedekatan, familiarity, daya tarik TTK dan daya tarik Apotek. Kuesioner yang telah dikonsultasikan disebarkan pada responden uji validitas dan reliabilitas kuesioner. Responden uji validitas dan reliabilitas adalah 30 pasien di luar sampel penelitian yang melakukan swamedikasi di apotek di Kota Denpasar. Responden tersebut harus memenuhi syarat sesuai kriteria inklusi dan eksklusi yang telah ditentukan.

Kuesioner yang disusun terdiri dari 66 pertanyaan dan 34 dari pertanyaan tersebut memiliki nilai $\mathrm{r}$ hitung $>0,361$ sehingga dinyatakan valid. Pertanyaan-pertanyaan yang dinyatakan valid disusun kembali dan diuji reliabilitasnya. Nilai Crobach's alpha yang diperoleh untuk kuesioner penelitian adalah 0.942. Hal tersebut menunjukan instrumen yang digunakan telah valid dan reliabel sehingga dapat digunakan untuk mengambil data penelitian. 


\section{Karakteristik responden penelitian}

Tabel 2. Deskripsi Karakteristik Responden Penelitian Berdasarkan Jenis Kelamin, Usia, dan Pendidikan pada Apotek Sampel di Denpasar

\begin{tabular}{|c|c|c|c|}
\hline \multicolumn{2}{|c|}{ Uraian } & Jumlah & Persentase \\
\hline \multirow{2}{*}{$\begin{array}{l}\text { Jenis } \\
\text { Kelamin }\end{array}$} & Laki-laki & 50 & $50 \%$ \\
\hline & Perempuan & 50 & $50 \%$ \\
\hline \multicolumn{2}{|c|}{ Total } & 100 & $100 \%$ \\
\hline \multirow{5}{*}{$\begin{array}{l}\text { Usia } \\
\text { (Tahun) }\end{array}$} & $17-25$ th & 48 & $48 \%$ \\
\hline & $26-35$ th & 19 & $19 \%$ \\
\hline & $36-45$ th & 11 & $11 \%$ \\
\hline & $46-55$ th & 14 & $14 \%$ \\
\hline & $56-65$ th & 8 & $8 \%$ \\
\hline \multicolumn{2}{|c|}{ Total } & 100 & $100 \%$ \\
\hline \multirow{5}{*}{$\begin{array}{l}\text { Pendidikan } \\
\text { terakhir }\end{array}$} & $\mathrm{SD}$ & 9 & $9 \%$ \\
\hline & SMP & 6 & $6 \%$ \\
\hline & SMA & 62 & $62 \%$ \\
\hline & Diploma & 8 & $8 \%$ \\
\hline & Sarjana & 15 & $15 \%$ \\
\hline \multicolumn{2}{|c|}{ Total } & 100 & $100 \%$ \\
\hline
\end{tabular}

Responden penelitian berjumlah 100 orang yang telah memenuhi kriteria inklusi dan eksklusi. Deskripsi karakteristik responden disajikan pada tabel 2.

Sebaran Hasil Penilaian Daya Tarik Fisik Apotek, Daya Tarik Fisik TTK, Familiarity, Kedekatan, Empati dan Kepercayaan Masyarakat Terhadap TTK di Apotek

Analisis deskriptif data yang telah diperoleh disajikan pada tabel 3, tabel 4, tabel 5, tabel 6, tabel 7 dan tabel 8 .

Tabel 3. Hasil Klasifikasi Tingkat Daya Tarik Fisik TTK

\begin{tabular}{c|c|c}
\hline No & Klasifikasi & Jumlah (Orang) \\
\hline 1 & Sangat Menarik & 53 \\
\hline 2 & Menarik & 47 \\
\hline 3 & Tidak Menarik & 0 \\
\hline 4 & Sangat Tidak Menarik & 0 \\
\hline
\end{tabular}

Pertanyaan yang terkait daya tarik fisik diantaranya apakah TTK yang bertugas selalu mengenakan seragam? Apakah TTK selalu terlihat segar saat bertugas? dan Apakah TTK selalu tersenyum ramah saat memberikan pelayanan? Kebanyakan responden menilai TTK sangat menarik. Pernyataan kuesioner dengan total skor terkecil yaitu: TTK yang bertugas di apotek ini selalu menggunakan seragam. Sebagian besar apotek tidak mewajibkan tenaga kefarmasian yang bertugas untuk menggunakan seragam saat bertugas.
Tabel 4. Hasil Klasifikasi Tingkat Daya Tarik Fisik Apotek

\begin{tabular}{ccc}
\hline No & Klasifikasi & $\begin{array}{c}\text { Jumlah } \\
\text { (Orang) }\end{array}$ \\
\hline 1 & Sangat Menarik & 50 \\
\hline 2 & Menarik & 50 \\
\hline 3 & Tidak Menarik & 0 \\
\hline 4 & $\begin{array}{c}\text { Sangat Tidak } \\
\text { Menarik }\end{array}$ & 0 \\
\hline
\end{tabular}

Daya tarik fisik Apotek dinilai berdasarkan ketersediaan pilihan metode pembayaran, cara pengemasan obat, kerapian dan kebersihan interior apotek, ketersediaan lahan parkir, ketersediaan TV dan koran atau majalah, dan ketersediaan obat. Pertayaan dengan jawaban paling rendah terdapat pada ketersediaan pilihan metode pembayaran. Kebanyakan apotek sampel belum memiliki pilihan metode pembayaran.

Familiarity dalam penelitian ini didefinisikan sebagai berikut : TTK yang bertugas di Apotek sudah familiar atau dikenal; dipahami; umum; sering; akrab. Tingkat Familiarity disajikan pada Tabel 5 .

Tabel 5. Hasil Klasifikasi Tingkat Familiarity

\begin{tabular}{clc}
\multicolumn{3}{c}{ TTK } \\
\hline No & \multicolumn{1}{c}{ Klasifikasi } & Jumlah (Orang) \\
\hline 1 & Sangat Familiar & 85 \\
\hline 2 & Familiar & 15 \\
\hline 3 & Tidak Familiar & 0 \\
\hline 4 & Sangat Tidak Familiar & 0 \\
\hline
\end{tabular}

Tabel 6. Hasil Klasifikasi Tingkat Kedekatan dengan TTK

\begin{tabular}{clc}
\hline No & \multicolumn{1}{c}{ Klasifikasi } & $\begin{array}{c}\text { Jumlah } \\
\text { (Orang) }\end{array}$ \\
\hline 1 & Sangat Dekat & 49 \\
\hline 2 & Dekat & 51 \\
\hline 3 & Tidak Dekat & 0 \\
\hline 4 & Sangat Tidak Dekat & 0 \\
\hline
\end{tabular}

Kedekatan dinilai berdasarkan kenyamanan dan kebebasan berkomunikasi, serta kesamaan gaya bicara. Kedekatan yang dimaksud adalah terdapatnya kesamaan antara TTK dengan responden, misalnya kesamaan tempat tinggal, kesamaan tempat lahir, kesamaan gaya bicara dan kesamaan kesenangan. Kedekatan tempat mampu menumbuhkan persahabatan seseorang dengan orang lain (Pieter, 2017). Taruna (2017) mengatakan dimulai dari adanya kesamaan tugas pekerjaan yang dilakukan, kedekatan tempat kerja, seringnya berjumpa dan barangkali adanya kesamaan kesenangan bersama, maka timbullah kedekatan satu sama lain. 
Tabel 7. Hasil Klasifikasi Tingkat Empati TTK

\begin{tabular}{clc}
\hline No & \multicolumn{1}{c}{ Klasifikasi } & $\begin{array}{c}\text { Jumlah } \\
\text { (Orang) }\end{array}$ \\
\hline 1 & Sangat Empati & 65 \\
\hline 2 & Empati & 35 \\
\hline 3 & Tidak Empati & 0 \\
\hline 4 & Sangat Tidak Empati & 0 \\
\hline
\end{tabular}

Empati TTK dinilai berdasarkan kemauan TTK untuk memberikan salam, kesopanan, keramahan, kesabaran, perhatian terhadap keluhan pasien, perhatian TTK untuk menanyakan kemajuan hasil pengobatan, serta kemauan TTK untuk memberikan informasi proaktif (informasi tanpa diminta). Empati yang dimaksud adalah keadaan mental yang membuat seseorang merasa atau mengidentifikasi dirinya dalam keadaan perasaan atau pikiran yang sama dengan orang atau kelompok lain. Ada bukti bahwa mayoritas pasien meyakini bahwa berbicara dengan tenaga kesehatan tentang obat-obatan adalah penting dan berguna. Mereka senang mendiskusikan kekhawatiran mereka ketika tenaga kesehatan mendorong mereka untuk melakukannya (Stevenson, 2004).

Tabel 8. Hasil Klasifikasi Tingkat Kepercayaan

\begin{tabular}{c|c|c}
\hline No & Klasifikasi & Jumlah (Orang) \\
\hline 1 & Sangat Percaya & 92 \\
\hline 2 & Percaya & 8 \\
\hline 3 & Tidak Percaya & 0 \\
\hline 4 & Sangat Tidak Percaya & 0 \\
\hline
\end{tabular}

Tingkat kepercayaan dinilai berdasarkan kemanfaatan informasi yang diberikan TTK, keterbukaan pasien untuk menyampaikan keluhan, keinginan untuk melakukan kunjungan balik ke apotek, kemauan pasien untuk mengikuti anjuran TTK, keyakinan pasien atas kerahasiaan pengobatan mereka, dan keyakinan pasien atas keberhasilan pengobatan atas bantuan TTK yang bertugas. Menurut Prasaranphanich (2007), ketika konsumen mempercayai sebuah perusahaan, mereka akan lebih suka melakukan pembelian ulang dan membagi informasi pribadi yang berharga kepada perusahaan tersebut. Terdapat dua pernyataan dengan nilai terkecil dari 10 butir pernyataan kuesioner kepercayaan yaitu pernyataan nomor 2 dengan pernyataan: Anda terbuka kepada TTK yang bersangkutan dalam menyampaikan keluhan-keluhan Anda. Dan pernyataan nomor 5 dengan pernyataan: Anda yakin TTK di apotek ini akan menjaga kerahasiaan tentang informasi keluhan anda.
Komunikasi merupakan proses yang sangat kompleks. Menurut Coiera (2006) suatu sistem komunikasi melibatkan orang-orang, pesan-pesan yang ingin mereka sampaikan, teknologi yang memediasi percakapan, dan struktur organisasi yang mendefinisikan dan membatasi percakapan yang dibiarkan terjadi. Ada tantangan organisasi dan tantangan komunikasi signifikan yang dihadapi oleh tenaga layanan kesehatan di masyarakat (Coiera, 2006). Tenaga kesehatan sering tidak siap untuk membantu pasien mengatasi rasa malu yang terkait dengan rendahnya kesadaran kesehatan. Selain itu, lingkungan institusi kesehatan sering menghalangi upaya petugas untuk menjelaskan secara menyeluruh cara mengobati atau mencegah penyakit dengan kata-kata yang dipahami pasien (Schwartzberg, 2007). Banyak penyedia layanan kesehatan yang mungkin memerlukan pendidikan khusus mengenai pengetahuan kesehatan masyarakat yang rendah dan implikasinya untuk sistem perawatan kesehatan, serta strategi untuk berkomunikasi dengan pasien yang memiliki pengetahuan kesehatan yang rendah (Ngoh, 2009).

\section{Analisis bivariat}

Analisis bivariat digunakan untuk melihat hubungan antara salah satu varibel bebas (Familiarity, Kedekatan, Empati, Daya Tarik Fisik TTK dan Daya Tarik Fisik Apotek) dan variabel terikat (tingkat kepercayaan masyarakat terhadap TTK di Apotek Kota Denpasar). Analisis bivariat dalam penelitian ini menggunakan Uji Korelasi Spearman. Pengujian dilakukan menggunakan SPSS 21 dengan taraf kepercayaan 95\%. Hasil pengujian menunjukkan ada korelasi antara kepercayaan masyarakat terhadap TTK dan semua variabel bebas yang diuji, kecuali faktor familiarity.

\section{Analisis multivariat}

Analisis multivariat bertujuan untuk menguji hubungan antara banyak variabel bebas dan satu variabel terikat. Analisis multivariat yang digunakan dalam penelitian ini adalah analisis regresi linear menggunakan SPSS 21 metode backward dengan taraf kepercayaan $95 \%$.

Hasil analisis menunjukkan dari lima faktor yang diuji hanya dua faktor yang dianggap cukup berpengaruh terhadap persamaan yaitu faktor empati dan daya tarik apotek. Persamaan yang diperoleh dari analisis regresi linear adalah: Kepercayaan masyakat terhadap TTK $=22,768+$ 0,295*empati $+0,330 *$ Daya Tarik Apotek.

Koefisien korelasi empati $=0,382$, sedangkan daya tarik apotek $=0,320$. Persamaan tersebut 
memiliki nilai $\mathrm{r}^{2}$ sebesar 0,332 . Nilai $\mathrm{r}^{2}$ yang semakin mendekati 1 menunjukkan persamaan yang semakin berkualitas. Nilai $\mathrm{r}^{2}$ dari hasil pengujian sangat kecil, sehingga dapat disimpulkan bahwa persamaan yang diperoleh belum dapat digunakan untuk menjelaskan faktorfaktor yang mempengaruhi tingkat kepercayaan masyarakat. Menurut hasil penelitian dimungkinkan ada banyak faktor yang mempengaruhi tingkat kepercayaan masyarakat terhadap TTK. Kemampuan TTK untuk menunjukkan empati dan kenyamanan apotek merupakan faktor - faktor yang cukup berpengaruh selain faktor lain yang tidak diuji dalam penelitian ini.

Tabel 9. Hasil Analisis Korelasi Spearman

\begin{tabular}{ccccl}
\hline No. & Variabel yang Dihubungkan & Signifikansi $(\mathbf{p})$ & Hubungan $(\mathbf{r})$ & \multicolumn{1}{c}{ Keterangan } \\
\hline 1. & Familiarity dan kepercayaan & $\mathrm{p}=0,224$ & 0,123 & $\begin{array}{l}\text { Korelasi tidak bermakna } \\
\text { dengan arah positif dan } \\
\text { kekuatan lemah. }\end{array}$ \\
2. & Kedekatan dan kepercayaan & $\mathrm{p}=0,031$ & 0,216 & $\begin{array}{l}\text { Korelasi bermakna } \\
\text { dengan arah positif dan } \\
\text { kekuatan lemah. }\end{array}$ \\
3. Empati dan kepercayaan & $\mathrm{p}<0,001$ & 0,507 & $\begin{array}{l}\text { Korelasi bermakna } \\
\text { dengan arah positif dan } \\
\text { kekuatan sedang. }\end{array}$ \\
4. Daya tarik fisik TTK dan kepercayaan & $\mathrm{p}=0,003$ & 0,296 & $\begin{array}{l}\text { Korelasi bermakna } \\
\text { dengan arah positif dan } \\
\text { kekuatan lemah. }\end{array}$ \\
5. Daya tarik Apotek dan kepercayaan & $\mathrm{p}<0,001$ & 0,437 & $\begin{array}{l}\text { Korelasi bermakna } \\
\text { dengan arah positif dan } \\
\text { kekuatan sedang. }\end{array}$ \\
\hline
\end{tabular}

Perlu usaha yang lebih besar dari tenaga kesehatan untuk membangun komunikasi yang efektif dengan pasien. Stevenson (2004) mengumpulkan data-data hasil penelitian tentang efek intervensi yang dirancang untuk meningkatkan aspek komunikasi dua arah tentang obat-obatan. Dua intervensi dirancang untuk mendorong pasien agar mengajukan pertanyaan dan ini ditemukan tidak terlalu efektif. Ketika intervensi dilakukan pada tenaga kefarmasian, ditunjukkan adanya peningkatan hasil kesehatan pasien, kepatuhan, kepuasan dengan layanan apoteker, komunikasi apoteker, pengetahuan pasien tentang penyakit dan pengobatan mereka, penurunan jumlah obat yang diresepkan, serta masalah terkait obat-obatan dan biaya pengobatan. Intervensi yang ditargetkan pada tenaga farmasi secara langsung, daripada pasien, lebih cenderung mendorong perubahan ke arah praktik yang sesuai. Ngoh dan Nkukuma (2009) menyatakan interaksi apoteker-pasien penting dalam memastikan bahwa pasien memiliki keterampilan dan pengetahuan yang diperlukan untuk melakukan pengobatan dan perawatan diri. Apoteker yang memiliki pengetahuan teknis diperlukan untuk membantu pasien terkait kebutuhan informasi obat dan perilaku minum obat. Terlepas dari pengetahuan ini, memberikan bantuan yang pasien butuhkan mungkin sulit karena aspek operasional tertentu dari praktik farmasi dan motivasi serta sikap apoteker.

Komunikasi provider-pasien merupakan faktor yang memiliki kontribusi dalam kepuasan pasien, kepatuhan, dan hasil kesehatan. Penelitian juga telah menunjukkan bahwa orang memahami dan mengingat apa yang penting bagi mereka, namun ada perbedaan yang signifikan antara apa yang ingin diketahui oleh pasien dan apa yang dianggap oleh para tenaga kesehatan harus diketahui pasien (Ngoh, 2009).

\section{SIMPULAN}

Ada banyak faktor yang mempengaruhi tingkat kepercayaan masyarakat terhadap TTK di Apotek. Penelitian ini menguji faktor-faktor yang berpengaruh pada tingkat kepercayaan jika diamati dari segi komunikasi. Faktor-Faktor tersebut diantaranya; daya tarik fisik TTK, daya tarik fisik Apotek, empati, familiarity, dan kedekatan. Jika masing masing faktor dianalisis korelasinya dengan tingkat kepercayaan pasien, hanya faktor familiarity yang dianggap tidak berpengaruh secara statistik. Sedangkan jika diuji secara simultan menggunakan regresi linear, hanya faktor empati dan daya tarik fisik apotek yang dianggap cukup berpengaruh terhadap persamaan yang dihasilkan. Dapat disimpulkan, selain faktor-faktor lain yang 
tidak termasuk dalam penelitian ini, untuk meningkatkan kepercayaan masyarakat TTK harus mampu menunjukkan empati pada pasien serta didukung oleh kenyamanan apotek.

\section{UCAPAN TERIMA KASIH}

Peneliti mengucapkan terima kasih yang sebesar-besarnya kepada berbagai pihak yang telah membantu terlaksananya penelitian ini diantaranya: Akademi Farmasi Saraswati Denpasar, Apotek Sedana, Apotek Akasia Farma, Apotek Orchid Medika, Apotek Bhuana Medika, I Gede Nyoman Jaya Nuraga, Ida Bagus Gede Dwi Ambara dan Ni Nyoman Triandani, Febrian Rachmansyah.

\section{DAFTAR PUSTAKA}

Antari N.P.U., Purnomo A, Sumarni. Difference In Outpatient's Expectation And Perception Toward Pharmacy Service Of Rsup Dr. Sardjito Yogyakarta And Rumah Sakit Bethesda Yogyakarta. J Manaj dan Pelayanan Farmasi (Journal Manag Pharm Pract. 2011; 1(2): 84-88. https://jurnal.ugm.ac.id/jmpf/article/view/2 $\underline{9354}$.

Coiera E. Communication Systems in Healthcare. Clin Biochem Rev. 2006;27(May). https://www.ncbi.nlm.nih.gov/pmc/articles/ PMC1579411/.

Gordon JE, Deland E, Kelly RE. Let' s Talk About Improving Communication in Healthcare. 2015; 1(May): 23-27. https://academiccommons.columbia.edu/doi 110.7916/D8959GTH.

Lemeshow S, Hosmer JDW, Klar J, Lwanga SK. Besar Sampel Dalam Penelitian Kesehatan. Yogyakarta: Gadjah Mada University Press; 1997.
Ngoh LN. Health literacy: A barrier to pharmacistpatient communication and medication adherence. J Am Pharm Assoc. 2009;49(5):e132-e149. doi:10.1331/JAPhA.2009.07075

Pieter HZ. Dasar-Dasar Komunikasi Bagi Perawat. Jakarta: Kencana; 2017.

Prasaranphanich. Perilaku Konsumen: Analisis Model Keputusan. Yogyakarta: Penerbitan Universitas Atma jaya Yogyakarta; 2007.

Rakhmat J. Psikologi Komunikasi. Bandung: PT Remaja Rosdakarya; 2011.

Schwartzberg JG, Cowett A, VanGeest J, Wolf MS. Communication techniques for patients with low health literacy: A survey of physicians, nurses, and pharmacists. Am J Health Behav. 2007;31(SUPPL. 1):96-104. doi:10.1109/ECODIM.1999.747668

Stevenson FA, Hons MA, Hons KC, Britten N, Hons BA. A systematic review of the research on communication between patients and health care professionals about medicines: the consequences for concordance. Heal Expect. 2004; 7(3): 235245.

https://www.ncbi.nlm.nih.gov/pmc/articles/ PMC5060245/.

Suharman ME, Husein RI. Pharmaceutical Care. Yogyakarta: Widya Padjadjaran; 2011.

Taruna JCT. Organisasi dan Pola-Pola Pendidikan Editor: Semarang: Universitas Katolik Soegijapranata; 2017.

Vermeir P, Vandijck D, Degroote S, et al. Communication in healthcare: a narrative review of the literature and practical recommendations. Int $\mathrm{J}$ Clin Pract. 2015;69(November):1257-1267. doi:10.1111/ijcp.12686 